\title{
Headteachers' Perception on the Utilization of Information Communications Technology (ICT) in the Management of Primary Education in Enugu State, Nigeria
}

\author{
Leo C. Chukwu \\ Department of Educational Management, Enugu State University of Science and Technology \\ (ESUT), Agbani, Enugu State, Nigeria
}

\begin{abstract}
The study examined the utilization of information communications technology (ICT) in the management of primary education in Enugu State, Nigeria. Three research questions and three null hypotheses guided the study. The research questions were answered using mean and grand mean scores, while the hypotheses were tested using t-test statistic at .05 level of significance and 286 degree of freedom. Descriptive survey research design was adopted for the study using a 20-item researcher developed instrument called; utilization of ICT in management questionnaire (UICTMQ). The population for the study comprised of all 1195 head teachers of all 1195 primary schools in Enugu State. The sample size was 318 respondents comprising 50\% of the 263 male head teachers and $20 \%$ of the 932 female head teachers. Following data analysis, findings reveal that ICT is utilized to a little extent in record keeping in primary schools in Enugu State. Also ICT is utilized to a little extent in teaching and learning as well as ensuring security in primary schools in Enugu state. Recommendations including; making ICT a compulsory component of primary school curriculum and providing functional ICT equipment in all the primary schools in Enugu State amongst others were put forward.
\end{abstract}

\section{Introduction}

At every stage of human development, change has remained an enduring phenomenon. Before his passing many years ago, my grandfather had very often recounted to me tales of how travelling on foot was the only means of transportation during their early years. $\mathrm{He}$ maintained that they usually travelled from my village Alechara Mgbowo, Enugu State to Baissa in the present day Taraba State all in Nigeria (a distance of more than five hundred kilometers) on foot. This distance took a few hours to cover using a motor vehicle and less than an hour using air plane. This is the revolution in transport systems. No sector of the human enterprise (health systems, education, agriculture, engineering, entertainment, communication) has been spared the change phenomenon. Utilization connotes the action of making practical and effective use of something. It means the use of resources.

\section{ICT Conceptualized}

To say that communication rules the world presently is an understatement. In untangling its vital place in every society, it is communication that holds groups together; families, schools, churches, various government organs and corporate entities. The world has become a global village through information communication technology (ICT). In the worlds of Chukwu and Aguba [3]:

$$
\begin{aligned}
& \text { ICT has revolutionized and } \\
& \text { simplified information } \\
& \text { dissemination, sharing, gathering } \\
& \text { and usage worldwide. Researchers, } \\
& \text { students, housewives, farmers, } \\
& \text { corporate personnel and } \\
& \text { businessmen could at the touch of a } \\
& \text { button access valuable information } \\
& \text { from any part of the world at } \\
& \text { breakneck speed through the } \\
& \text { information super highway } \\
& \text { (internet). ICT has made } \\
& \text { globalization faster and easier. }
\end{aligned}
$$

The researchers agree completely with the above postulation. Iwu, Ike and Chimezie [5] posit that ICT is the acquisition, processing, storage and dissemination of vocal, practical, textual and numeric information by a microelectronic based combination of computing and telecommunication. The above definition implies that ICT has the capacity for multiple application. ICT is the use of computer to process, store and transmit data. It is a medium used to describe exciting and innovative ways of providing lifelong 
learners with global access to information [1].

Contributing, Uchegbu [11] asserts that ICT mostly refers to computers and the internet. It is a term that refers to more than just computers. Siraj-Blatchford and white bread in Chukwu [2] aver that ICT is anything which allows us to get information, to communicate with each other or have an effect on the environment using electronic or digital equipment. It could consist of the following hardware and software types, computers, video cameras, internet, telephones, tape recorders, television, projectors, electronic whiteboards, programmable toys amongst others.

Olutunji [8] maintains that information communication technology is a marriage of two advanced technologies computing (Manipulating information) and communicating. Olutunji contends that ICT has to do with the storage, retrieval, manipulation and dissemination of information and all equipments involved. These equipments include;

- Technology for broadcasting information -radio, television camcorder

- Technology for communicating through voice and sound or images -microphones, digital cameras, loudspeakers, telephones and cellular phones.

- Others portables, including calculators.

ICT is the effective utilization of the information superhighway (internet) for multiple applications, including information gathering, dissemination, storage, retrieval and utilization.

\subsection{Benefits of ICT in Education}

ICT has been found very useful and is widely utilized in every sphere of human endeavour. In education sector, Oloruntegbe [6] lists the benefits of ICT in schools to include:

- Teachers are exposed to e-learning which is capable of instant updating, storage/retrieval, distribution and sharing of instruction and information.

- The teacher benefits from the dynamism of ICT to demonstrate some difficult science concepts, principles and theories, thereby giving meaning to classroom instruction and making lesson presentation not only exciting but very interesting.

Equally, ICT:

- promotes learning by doing approach i.e. hands on approach to learning;

- enables self-paced learning;

- enriches learning through a combination of audio, video, images, text and animation;

- enhances learning through interaction and collaboration;
- provides a platform that engages students.

Anulobi and Anulobi [1] further highlights the

benefits of ICT in education to include:

- It is used as a supplement and alternative to conventional teaching methods.

- It helps to improve and develop the learning abilities of the learners.

- ICT helps many people to become educated through distance education.

- ICT could be used outside the school environment e.g. for home teaching and learning.

It is important to add that:

a. ICT is an important tool for improving the child's cognitive, affective and psychomotor domains of learning.

b. It is a veritable instrument for intense and result oriented research in all fields of learning.

c. ICT is an indispensable and reliable tool for data collection and analysis.

Oludotun [7] and Siddiqui [9] agree that the use of ICT instructional materials in primary education has focused on improving the quality of education offered in the schools. ICT instructional materials has offered the means to meet the challenges, extend access to education to the remotest regions and serve those who do not have the option of face to face learning.

\section{Management Conceptualized}

There is no general consensus amongst writers as to the definition of the concept, management. What is certain is that each scholar sees the concept from his/her perspective. It is clear and unargueable however that management involves people, material resources, managing the human and material resources and the achievement of predetermined goals. In this line of thought, Ejieh in Igwe [4] posits that management is the specific process of organizing and controlling performance to determine and accomplish stated objectives with the use of human and material resources.

Management is the deliberate attempt at streamlining the human and material resources in organizations in order to actualize set objectives. It is a conscious effort aimed at utilizing available resources to their optimal level in order to achieve stated objectives. Management involves the harnessing of human and material resources in an organization in order to achieve stated goals [4]. Contributing, Daft in Unachukwu [12] maintains that management is the attainment of organizational goals in an effective and efficient manner through planning, organizing, leading and controlling organizational 
resources. Citing Bhagwan and Bhushan, Sule [10] argues that management is the process of directing and facilitating the work of people organized in formal groups to achieve a desired goal. Management is basically the effective and efficient coordination of available men and materials in order to achieve predetermined goals. Effective and efficient management of available human and material resources for achieving the stated goals of basic education in Enugu becomes compelling. The functions of management include but not limited to the following processes; planning, organizing, leading and controlling. Educational and other managers must first plan, then lead others work towards the plan and finally evaluate the effectiveness of the plan

\section{Concept of Primary Education}

In Nigeria, primary education is the foundation of the formal education ladder. According to federal Republic of Nigeria FRN (2013:21-22) primary education is the education given to children aged 6-12 years. The objectives of primary education include to;

1. inculcate permanent literacy, numeracy and the ability to communicate effectively;

2. lay a sound basis for scientific, critical and reflective thinking;

3. promote patriotism, fairness, understanding and national unity;

4. instill social, moral norms and values in the child;

5. develop in the child the ability to adapt to the changing environment, and

6. provide opportunities for the child to develop life manipulative skills that will enable the child function effectively in the society within the limits of the child's capacity.

The aforestated objectives reveal clearly that primary education is very strategic in the overall development of the child. The child of course is not just tomorrow's leader, but a very useful and contributing member of the society. It becomes equally clear that primary education must be qualitative to serve both the individual and the society optimally. We live in an age of information explosion and dissemination. We live in the $21^{\text {st }}$ century powered by ICT. Effective utilization of information communications technology at the primary level of education becomes imperative.

\section{Theoretical Underpinning}

The present study was anchored on the theory of technological determinism advanced by Thorstein Veblen (1857-1929). Technological determinism is a reductionist theory that assumes that a society's technology determines the development of its social structure and cultural values. Technological determinism tries to understand how technology has had an impact on human behaviour and thought. The theory is relevant to the present study because ICT has had a huge impact on the peoples' social structures and cultural values both here in Enugu State and elsewhere. Communication system and social relations has been revolutionized. In the educational sector especially primary education, ICT has greatly impacted on and will continue to revolutionize research, teaching and learning.

\section{Statement of the Problem}

It is a known fact that the ICT revolution has touched all facets of the human enterprise. In education, ICT has become a veritable tool for effective management, research, teaching and learning. The extent to which ICT is utilized in the management process in primary schools in Enugu State is uncertain. This forms the problem of the present study. This could be put in question form thus; to what extent is ICT utilized in the management of primary education in Enugu State.

\section{Research Questions}

The following research questions were formulated to guide the study;

1. To what extent is ICT utilized in record keeping in primary schools in Enugu State?

2. To what extent is ICT utilized in classroom instruction in primary schools in Enugu State?

3. To what extent is ICT utilized in ensuring security in primary schools Enugu State?

\section{Hypotheses}

The following null hypotheses tested at .05 level of significance were formulated to guide the study;

1. There is no significant difference in the mean response scores of male and female headteachers on the extent of utilization of ICT in record keeping in primary school in Enugu State

2. There is no significant difference in the mean response scores of male and female headteachers on extent of the utilization of ICT in classroom instruction in primary schools in Enugu State

3. There is no significant difference between the mean response scores of male and female headteachers on the extent of utilization of 
ICT in ensuring security in primary schools in Enugu State

\section{Method}

Descriptive survey research design was adopted for the study using a researcher developed 20-item instrument called; utilization of ICT in management questionnaire (UICTMQ). The instrument was designed with a four point scale of Very Great Extent (VGE) 4 points, Great Extent (GE) 3 points, Little Extent (LE) 2 points and Very Little Extent (VLE) I point. There were 263 male and 932 female headteachers in Enugu State making a total population of 1195 respondents for the study. Nwana in Uzoagulu (2011) maintains that the circumstance(s) of each study should help a researcher determine the sample size for the study. The researcher used $50 \%$ of the male and $20 \%$ of the female headteachers respectively. This followed the disparity in both populations, plus the fact that the higher the sample size, the smaller the margin of error. There were therefore, 132 male and 186 female headteachers used for the study making a sample size of 318 respondents. The use of headteachers was as a result of their experience, strategic and indispensable positioning in primary education administration and management. This places them in a vantage position to respond appropriately to issues pertaining to utilization of ICT in the management of primary education in Enugu State.

The instrument for data collection was validated by three experts. Two of the experts are in Educational Management, while one is in Measurement and Evaluation. All the experts were from the Faculty of Education, ESUT, Agbani, Enugu. The reliability coefficient of the instrument was determined using Cronbach Alpha. This followed trial testing of the instrument with 20 headteachers in Ebonyi State which has similar characteristics and shares boundary with Enugu State. Alpha values for clusters 1,2 and 3 yielded.65 0.67 and 0.68 respectively. Overall reliability coefficient yielded 0.71 indicating a high reliability of the instrument for the study. Of the 132 copies of the questionnaire administered on the male headteachers, 120 were well completed and returned giving a return rate of $91 \%$. Also of the 186 questionnaire given out to female head teachers, 168 were well completed and returned giving a return rate of $90 \%$. Equally, of the 318 questionnaire given out to the entire respondents, 288 were returned giving a return rate of $91 \%$.

For data analysis and decision rule, any item with mean of 2.50 and above was regarded as great extent, while any mean less than 2.50 was regarded as little extent. The mean average was obtained by summing up the values of the four point scale and dividing the value by the number of the four point scale thus;

$$
\frac{4+3+2+1}{4}=\frac{10}{4}=2.50
$$

For the hypotheses, when t-calculated is equal to or greater than $\mathrm{t}$-critical, the null hypothesis was rejected, meaning there was significant difference between the mean scores of both male and female headteachers. Conversely, when t-calculated was less than the critical value, the hypothesis was not rejected indicating there was no significant difference between the mean scores of both groups of respondents. Table 1: Mean scores, grandmean and standard deviation of respondents on the extent to which
ICT is utilized in record keeping in primary schools in Enugu State.

\begin{tabular}{|c|c|c|c|c|c|c|c|c|c|c|c|c|c|c|c|}
\hline \multirow[t]{2}{*}{$\mathbf{S} / \mathbf{N}$} & \multirow{2}{*}{$\begin{array}{l}\text { Items } \\
\text { In my school, ICT } \\
\text { is utilized in } \\
\text { keeping record } \\
\text { in; }\end{array}$} & \multicolumn{7}{|c|}{$\mathrm{N}=120$ Male Head teachers } & \multicolumn{7}{|c|}{$\mathrm{N}=168$ Male Head teachers } \\
\hline & & $\begin{array}{c}\text { VGE } \\
4\end{array}$ & $\begin{array}{c}\mathrm{GE} \\
3\end{array}$ & $\begin{array}{l}\mathrm{LE} \\
2\end{array}$ & $\begin{array}{c}\text { VLE } \\
1\end{array}$ & $\bar{X}$ & SD & Dec. & $\underset{4}{\mathrm{VGE}}$ & $\begin{array}{r}\mathrm{GE} \\
3\end{array}$ & $\begin{array}{r}\mathrm{LE} \\
2\end{array}$ & $\begin{array}{c}\text { VLE } \\
1\end{array}$ & $X$ & SD & Dec. \\
\hline 1. & Pupils biodata & 8 & 13 & 36 & 63 & 1.72 & 0.91 & LE & 10 & 12 & 13 & 133 & 1.40 & 0.86 & LE \\
\hline 2. & $\begin{array}{l}\text { Pupils } \\
\text { guardian/parents, } \\
\text { biodata }\end{array}$ & 11 & 15 & 34 & 60 & 1.81 & 0.98 & LE & 13 & 19 & 30 & 106 & 1.64 & 0.96 & LE \\
\hline 3. & $\begin{array}{l}\text { School yearly } \\
\text { calendar of } \\
\text { events }\end{array}$ & - & 8 & 20 & 92 & 1.30 & 0.59 & LE & 11 & 18 & 25 & 114 & 1.56 & 0.93 & LE \\
\hline 4. & $\begin{array}{l}\text { Pupils } \\
\text { examination } \\
\text { results }\end{array}$ & - & 7 & 18 & 95 & 1.27 & 0.56 & LE & 8 & 11 & 32 & 117 & 1.46 & 0.82 & LE \\
\hline 5. & $\begin{array}{l}\text { School's financial } \\
\text { record }\end{array}$ & 4 & 12 & 17 & 87 & 1.44 & 0.81 & LE & 14 & 19 & 26 & 109 & 1.63 & 0.98 & LE \\
\hline 6. & $\begin{array}{l}\text { Important events } \\
\text { such as visits of } \\
\text { dignitaries }\end{array}$ & 6 & 15 & 19 & 80 & 1.56 & 0.90 & LE & 9 & 20 & 31 & 108 & 1.58 & 0.90 & LE \\
\hline
\end{tabular}




\begin{tabular}{|c|c|c|c|c|c|c|c|c|c|c|c|c|c|c|c|}
\hline 7. & Schools history & - & 11 & 12 & 97 & 1.28 & 0.62 & $\mathrm{LE}$ & 15 & 17 & 24 & 112 & 1.61 & 099 & LE \\
\hline 8. & School curriculum & 5 & 13 & 18 & 84 & 1.49 & 0.85 & LE & 19 & 25 & 33 & 91 & 1.83 & 1.06 & LE \\
\hline \multirow[t]{2}{*}{9.} & $\begin{array}{l}\text { School's vision \& } \\
\text { mission }\end{array}$ & 3 & 10 & 21 & 86 & 1.42 & 0.75 & LE & 11 & 18 & 27 & 112 & 1.57 & 0.93 & LE \\
\hline & $\begin{array}{l}\text { Grand mean \& } \\
\text { SD }\end{array}$ & & & & & 1.48 & 0.77 & LE & & & & & 1.59 & 0.94 & LE \\
\hline
\end{tabular}

Data as presented in table 1, indicated that there were grandmean of 1.48 and 1.59 for male and female headteachers respectively. This shows that ICT is utilized to a little extent in record keeping in primary schools in Enugu State.

Table 2: Mean Scores, grandmean and Standard Deviation of respondents on the extent to which ICT is utilized in Classroom teaching and learning in primary school in Enugu State

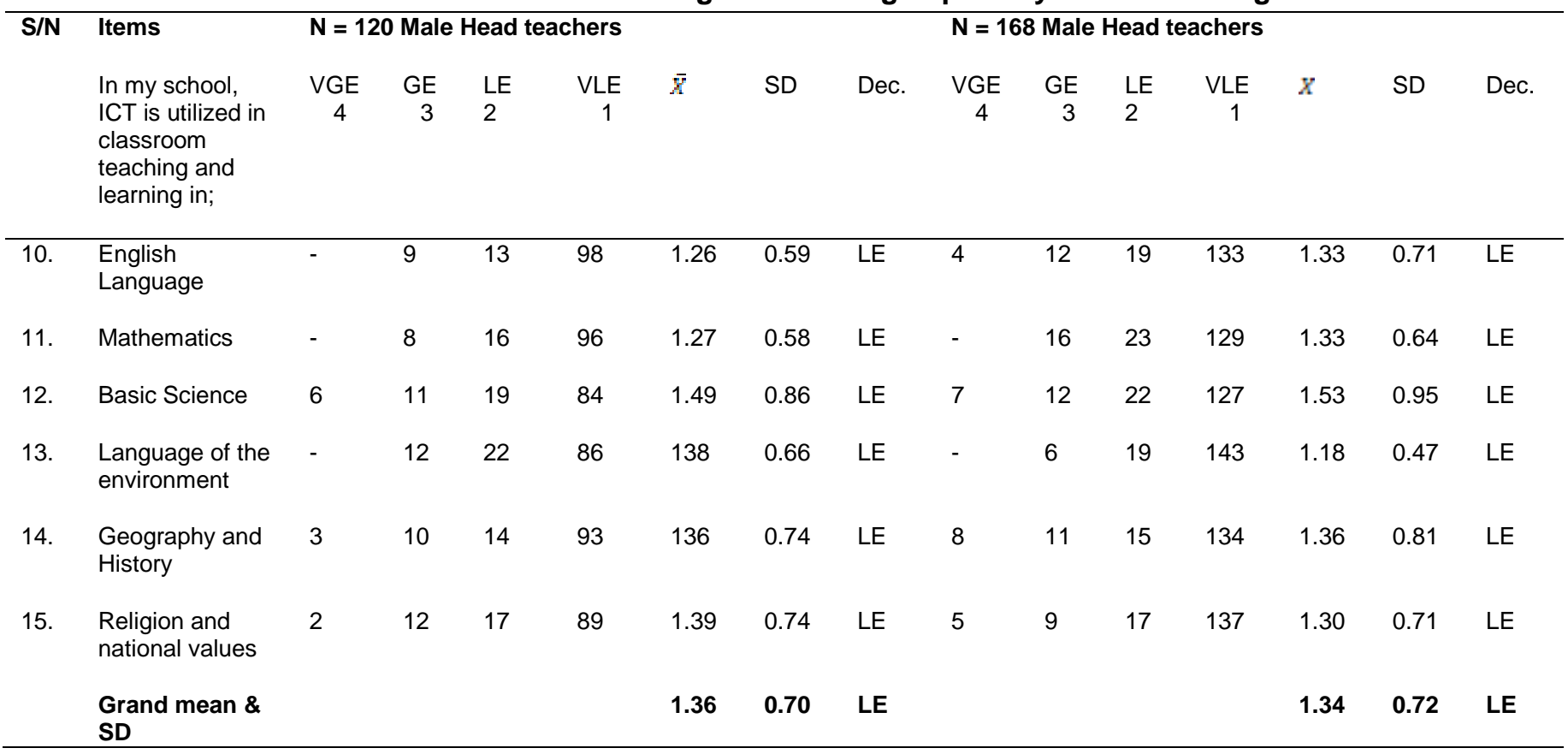

Data as presented in table 2 reveal that there were grandmeans of 1.36 and 1.34 respectively for both male and female headteachers. This indicates that ICT is utilized to a little extent in classroom instruction in primary schools in Enugu State.

Table 3: Mean Scores, grandmean and Standard Deviation of respondents on the extent to which ICT is utilized in ensuring security in primary schools in Enugu State

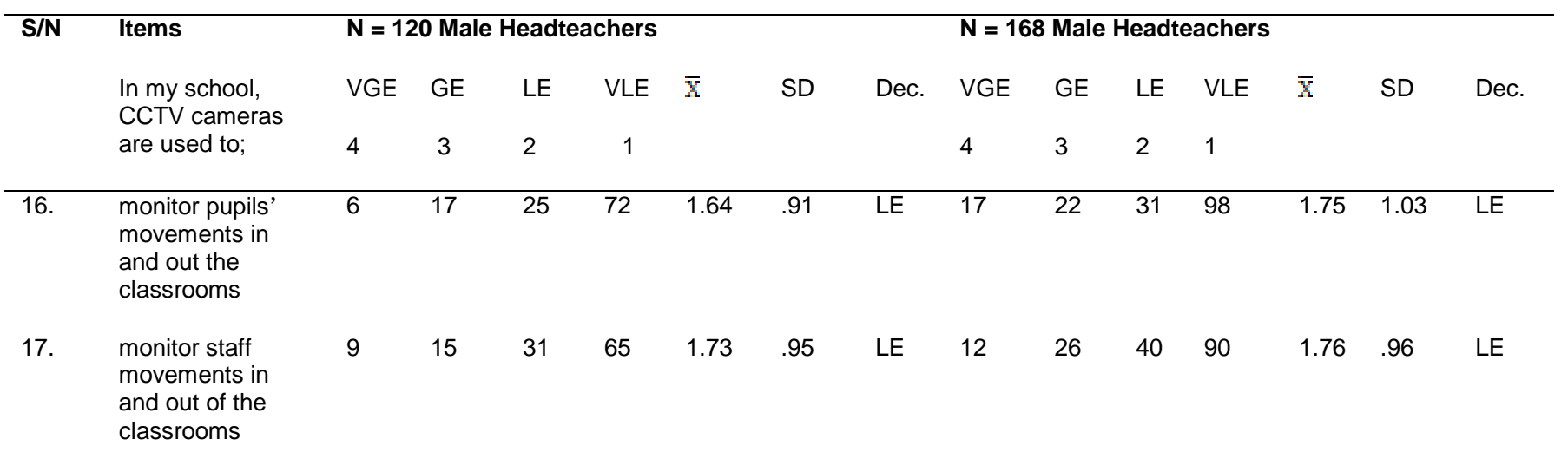




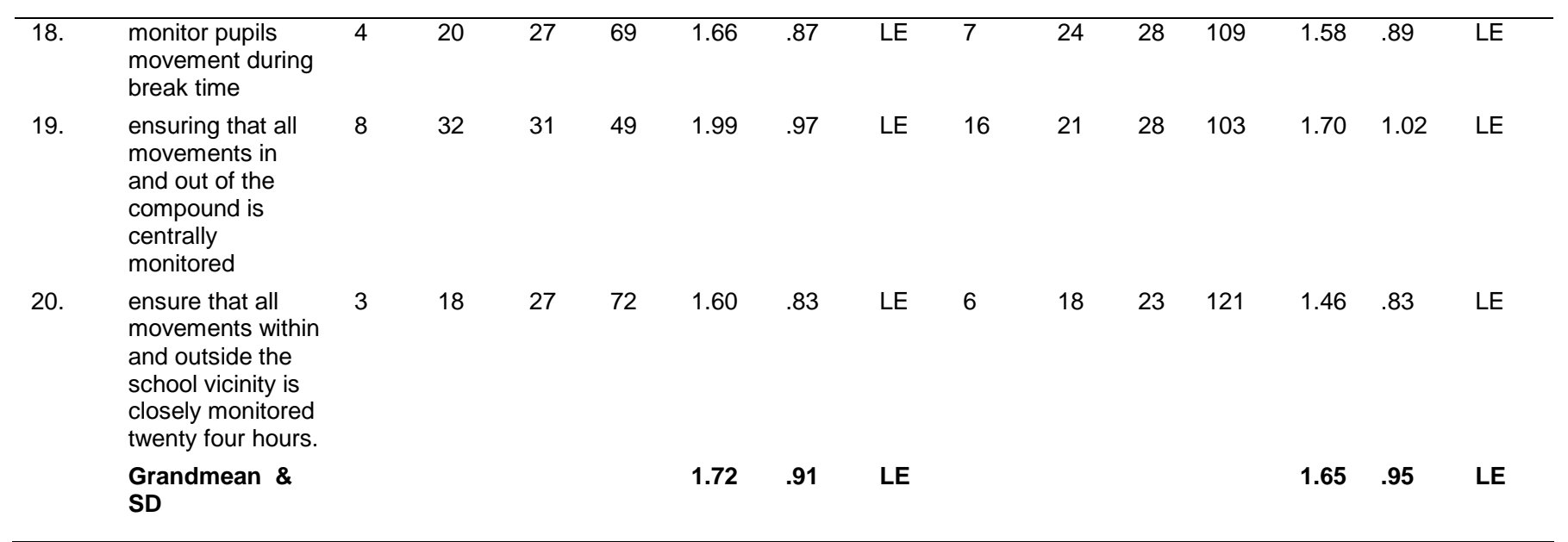

Data as presented in table 3 indicates that the grandmeans of 1.72 and 1.65 for male and female headteachers respectively. This indicates that ICT is utilized to a little extent in ensuring security in primary schools in Enugu State.

Table 4: t-test of significant difference between the mean scores of male and female headteachers on the extent to which ICT is utilized in record keeping in primary schools in Enugu State

\begin{tabular}{|c|c|c|c|c|c|c|c|}
\hline Respondents & $\mathbf{N}$ & $\bar{X}$ & SD & df & t-cal & t-crit & Decision \\
\hline Male headteachers & 120 & 1.48 & 0.77 & & & & Not significant \\
\hline Female headteachers & 168 & 1.59 & 0.94 & 286 & 1.1 & 1.96 & \\
\hline
\end{tabular}

Table 4 indicate that t-calculated of 1.1 is less than t-crit of 1.96 at .05 level of significance and 286 degree of freedom. The hypothesis was therefore not rejected. There was therefore no significant difference between the mean responses of both groups of respondents.

Table 5: t-test of significant difference between the mean scores of male and female headteachers on the extent to which ICT is utilized in classroom teaching and learning in primary schools in Enugu State

\begin{tabular}{llllllll}
\hline Respondents & $\mathbf{N}$ & $\bar{X}$ & SD & df & t-cal & t-crit & Decision \\
\hline Male headteachers & 120 & 1.36 & 0.70 & & & & Not significant \\
Female headteachers & 168 & 1.34 & 0.72 & & & & \\
\hline
\end{tabular}

Table 5 above reveals that t-calculated of 0.24 is less than t-critical of 1.96 at .05 level of significance and 286 degree of freedom. The null hypothesis was therefore not rejected. This implies that no significant difference exist between the mean response scores of both groups of respondents.

Table 6: t-test of significant difference between the mean response scores of male and female headteachers on the extent to which ICT is utilized in ensuring security in primary schools in

\begin{tabular}{llllllll}
\hline Respondents & N & $\bar{X}$ & SD & df & t-cal & t-crit & Decision \\
\hline Male headteachers & 120 & 1.72 & 0.91 & & & & Not significant \\
Female headteachers & 168 & 1.65 & 0.95 & & & & \\
\hline
\end{tabular}


Date in table six indicates that t-calculated of 0.64 is less than t-crit of 1.96 at 286 degree of freedom. The hypothesis was therefore not rejected, meaning that there was no significant difference between the mean response of both groups of respondents.

\section{Findings of the Study}

The following are the findings of the present study.

1. ICT is utilized to a little extent in record keeping in primary schools in Enugu State

2. ICT is utilized to a little extent in teaching and learning schools in Enugu State

3. ICT is utilized to a little extent in ensuring security in primary schools in Enugu State, Nigeria.

4. There is no significant difference between the mean response scores of both male and female headteachers on the extent to which ICT is utilized in record keeping in primary schools.

5. There is no significant difference between the mean response scores of both groups of respondents on the extent to which ICT is utilized in teaching and learning in primary schools in Enugu State.

6. There is no significant difference between the mean response scores of male and female headteachers on the extent to which ICT is utilized in ensuring security in primary schools in Enugu State.

\subsection{Discussion of the Findings}

The study found that ICT is utilized to a little extent in record keeping as well as classroom instruction and ensuring security in primary schools in Enugu State. This is not a pleasant situation in any way. This is because ICT has revolutionized our lives in virtually every sector, including education. Anulobi and Anulobi [1] submit that ICT is the use of computer to process, store and transmit data. They maintain that ICT is a medium used to describe exciting and innovative ways of providing (life long) learners with global access to information.

Oloruntegbe [6] and Anulobi and Anulobi [1] highlights some of the benefit of ICT to include among others.

1. Teachers benefit from the dynamism of ICT to demonstrate some difficult science concepts, principles and theories, thereby giving meaning to classroom instruction and making lesson presentation not only exciting, but very interesting.

2. ICT helps to improve and develop the learning abilities of the learners.

3. It is used as a supplement and alternative to conventional teaching methods.
From the foregoing, it is clear that the pupils in Enugu State primary schools system are missing out on the many advantage of ICT especially in the education sector. It becomes important that the status quo be changed for the benefit of both teachers and pupils, as far as primary education is concerned in Enugu State.

\section{Conclusion}

Primary education is the foundation upon which the rest of the educational ladder rests, thereby determining largely the success or failure of the other levels of education. It therefore becomes vital that this sector is made ICT compliant to enhance record keeping as well as classroom teaching and learning and security amongst others.

\section{Recommendations}

Following the findings of the study, the following recommendations were made;

1. ICT should be made a compulsory component of primary education curriculum in Enugu State.

2. All primary schools in Enugu State should be provided with a full complement of ICT equipment and linked to the internet in order to be benefiting from ICT assisted teaching and learning.

3. Infrastructure should be improved particularly by ensuring constant power supply as ICT cannot function effectively, without electricity.

4. Constant workshops, seminars and conferences should be organized for primary school teachers to enhance their knowledge of ICT so they can transfer same to the learners.

5. CCTV cameras should be provided in primary schools to enhance security of lives and property in the schools.

\section{References}

[1]. Anulobi, J.C. \& Anulobi, R.C. (2011). Availability and utilization of information communication Technology (ICT) instructional materials in primary schools in Owerri. African Journal of Allied Education (ATAE) 5(2), 208-220.

[2]. Chukwu, L.C. (2012). ICT compliant basic education: A basis for scientific and technological revolution in Enugu State. ESUT Journal of Education (ESUTJE). 1(3), 29-35.

[3]. Chukwu, L.C. \& Aguba, C.R. (2015). Adopting ICT in human capital development in Enugu State: Implications for 
quality assurance in secondary schools. Journal of Global Studies (JOGS). 3(1), 41-45.

[4]. Igwe, C.A. (2016). Quality management in the Nigerian secondary school system. Nigerian Journal of Educational Administration and Management: (NJEAM), 1(12), 129-136.

[5]. Iwu, A.O., Ike, G.A. \& Chimezie, O.S. (2006). Perspectives on Educational Technology. Owerri: Peace Publishers Limited.

[6]. Oloruntegbe, K.O. (2007). Compenduim of ICT resources for chemistry teachers. African Journal of Allied Education (AJAE) 1(1), 242-250.

[7]. Oludotun, J.S.O. (2005). Importance of information and communication technology in science and technology education for development. In U.O. Uduogie (Ed). Science and Technology Education for development. Lagos: NERDC Press.

[8]. Olutunji, O. (2010). Teaching and learning secondary school mathematics with ICT: A practical approach. Lecture notes programme and introductory manual. Workshop for Retraining of primary school teachers on the implementation of New- UBE curriculum and continuous assessment in schools for SUBEB in Enugu State with National Mathematical centre. Abuja. Pp 75-87.

[9]. Siddiqui, M. H. (2008). Distance learning technology in education. New Delhi: APH Publishing Corporation.

[10]. Sule, S.A. (2016), Management of Innovation procedure, In C.C Uchendu \& B.A. Akuegwu (Eds). Educational Management: A guide for practitioners. Calabar: University of Calabar Press.

[11]. Uchegbu, C.N. (2010). Role of Information and communication technology (ICT) in the dissemination of HIV/Aids and sexuality related information in Nigeria. African Journal of Allied Education (AJAE). 4(1) 154-162.

[12]. Unachukwu, G.O. (2014). Leadership in formal organizations. In G.O. Unachukwu \& P.N. Okorji (Eds). Educational Management: A skills building approach. Nimo: Rex Charles and Patrick Limited. 